\title{
LIST OF FISHES COLLECTED IN THE VICINITY OF NEW ORLEANS BY DR. R. W. SHUFELDT, U. S. A.
}

By DA VID S. JORDAN.

In the winter of 1882-'83 a collection of fishes was made in the vicinity of New Orleans by Dr. R. W. Shufeldt for the U. S. National Museum. In the present paper is given a catalogue of the fresh and brackish water species included in this collection. The collection was received at the Museum February 21, 1883.

1. Scaphirhynchops platyrhynchus, (Raf.). (No. 32475.)

Dorsal shields 17 ; lateral 41.

2. Amia calva, L. 35243, 35244 .

3. Amiurus natalis, (Le Sueur). 35209 (5).

Color dark ; form robust; spines short; pectoral spine not half head. Head, $3 \frac{3}{4}$; depth, $3 \frac{3}{4}$; A. 26 ; in specimen $7 \frac{1}{2}$ inches long.

4. Ictalurus punctatus, (Raf.). 25219, 25291.

Anal rays, 25-26. Dark spots few in one specimen, obsolete in the other.

5. Ictalurus furcatus, (C. \& V.). $35218,32477,33820$.

Anal rays, 34 in each.

6 Ictiobus ? cyprinella, (C. \& V.). 35221, 35230.

Young specimens.

7. Ictiobus ? urus, (Ag.). 35222, 35229 .

Young.

8. Ictiobus ?cyprinus, (Le Sueur). 35204 (3).

Largest, $6 \frac{1}{4}$ inches long. Head, 4 in length; depth, $2 \frac{2}{3}$. Longest dorsal ray, $1 \frac{1}{4}$ in base of fin. Anterior rays not thick at base. Snout not very obtuse. Angle of mouth below front of eye. D. ii, 24. Scales, 6-37-5.

9. Erimyzon sucetta, (Lac.). 35220, 35290, 35292.

Specimens less than 6 inches long, but with three large tubercles on each side of snout before eye. Head, $3 \frac{5}{6}$ in length; depth, $3 \frac{1}{5}$. D, 11 . Scales, 36-13, 37-13, 39-13.

These specimens approach the type of $E$. goodei, to which species they should perhaps be referred. Very likely E. sucetta and E. goodei may be found to intergrade.

10. Notemigonus chrysoleucus, (Mitchill). 35199 (5).

Anal rays, ii, 13 . Scales, 48 to 50. 
In the genus Notemigonus, as already noticed by Dr. S. A. Forbes, the gill-rakers are numerous, slender, and comparatively long. In the allied genus, Richardsonius, of the Pacific coast, the gill-rakers are few and very short.

11. Dorosoma cepedianum exile, Jordan \& Gillert. 35195,35232 to $35 * 39$.

The numerous specimens, large and small, seem to be referable to the slight variety exile, established by us on Galveston specimens. Examples, 13 inches long, have the depth $2 \frac{3}{4}$ to $2 \frac{9}{10}$ in length ; those 7 inches long, $2 \frac{5}{6}$ to 3 . The number of anal rays seems to vary considerably, the following numbers being counted on nine specimens: ii, 30; ii, 31; ii, 32 ; ii, 33 ; ii, 34 (3); ii, 35 (2).

Scales about 58 ; scutes $17+12$. Dorsal rays 1,12 . Dorsal filament about as long as head.

12. Esox vermiculatus, Le Sueur. 35208.

Color very dark; fins somewhat dusky. Sides with about 30 narrow, reticulating cross-streaks; a dark bar below eye. Lips blackish. B. 11-12. D. iii, 13. A. ii, 12. Eye very slightly before middle of head. Head $3 \frac{1}{4}$ in length.

13. Fundulus ? ocellaris, Jordan \& Gilbert. 35226 (6 ठ ); 35227 (4 \&).

Numerous specimens of a species of Fundulus, which seems to agree with Fundulus ocellaris in all tangible respects, but differs widely in color from the types of that species, as will be seen from the following:

Males with about 15 sharply defined cross-bands, as broad as or broader than the silvery interspaces. A few dark dots on upper parts. Dorsal and anal with pearly dots. Few or none of these on body. Females light olive, with many small dark spots, which form obscure series. Larger spots, as large as pupil, scattered over sides of body. No trace of dark cross-bands. Dorsal with a conspicuous black ocellus on its last rays, as in F. ocellasis.

Dorsal fin low and small, inserted a litele before the small anal. Oviduct extending around base of first anal ray. D. ca. 10 ; A. ca. 10. Scales 34-13. Head, $3 \frac{3}{5}$ in length ; depth, $3 \frac{4}{5}$. Interorbital width, $2 \frac{1}{10}$ in head. Eye equal to suout, $4 \frac{1}{5}$ in head. Largest specimen $2 \frac{1}{2}$ inches in length.

In spite of the marked difference in color, I hesitate to regard this as specifically distinct from Fundulus ocellaris.

14. Zygonectes chrysotus, (Günther). $32412(6) ; 32414$ (6);32420 (4).

? Fundulus cingulatus, Cuv. \& Val. $\delta$ ?.

Zygonectes cingulatus, Jordan \& Gilbert. Not Hydrargyra lucia, Baird.

Numerous specimens agreeing well with the description given by us in Proc. U. S. Nat. Mus., 1882, 586, of Zygonectes cingulatus and with Dr. Günther's Haplochilus chrysotus. It may be the Fundulus cingulatus scantily described by Valenciennes, but of this there is no certainty, 
and the latter species is said to have 16 cross-bands. Hydrargyra lucice Baird has a dorsal ocellus, and is most likely some other fish.

Head, $3 \frac{3}{4}$ to 4 in length; depth, $3 \frac{4}{5}$. D. 8 or 9. A. 11. Scales, 33-12. Length of longest specimen, $2 \frac{1}{3}$ inches.

Color dusky aibove, the sides with faint pearly dots, which are most conspicuous in the female. Males with the dorsal and caudal dotted, the latter most so, the dots sometimes arranged in cross-series, sometimes irregularly scattered. Male with about 10 narrow dark crossbands. Female without bands, the fins entirely plain dusky. No black blotch below eye. No dorsal ocellus in either sex.

15. Gambusia patruelis, Baird \& Girard. 35196, 32413, 32422.

Many specimens, mostly females, not gravid. I find it extremely difficult to distinguish large females of this species from the typical specimen of Zygonectes inurus, with which I have compared them. It is probable that the typical example of the latter species is really a large Gambusia.

16. Mollienesia latipinna, Le Sueur. 35197; 35210; 35211; 35216; 32415; 32416; 32418 ; 32421.

(Mollienesia lineolata, Girard.)

These specimens do not confirm the validity of the distinctions between M. latipinna and M. lineolata given by us in Proc. U.S. Nat. Mus., 1882, 259. It is probable that no permanent difference exists.

17. Anguilla rostrata, (Le Sueur). 35215 (5).

18. Elassoma zonatum, Jordan. 32423 (14).

A specimen about an inch in length. Coloration very dark; eight cross-bands broader than the interspaces; a dusky scapular blotch; a dark blotch below eye. Dorsal, anal, and caudal with narrow, distinct, dark cross-bands; pale parts of body everywhere soiled with dark points.

Head, 3 in length; depth, 3 . D. IV, 11 ; A. III, 5 or 6 . Scales, about 36 .

18. Micropterus salmoides, (Lac.). 35200 .

19. Lepomis cyanellus, Raf. $35198 ; 35201$.

Numerous specimens, varying considerably in form of body.

20. Lepomis symmetricus, Forbes. $35213 ; 32410 ; 32419$.

Numerous specimens, the largest $3 \frac{1}{8}$ inches in length, agreeing closely with Dr. Forbes's original description, and with one of his types (29864).

Head, $2 \frac{5}{6}$; depth, $2 \frac{1}{1} 0$. D. X, 9; A. III, 9. Scales, 5-33-13. Mouth much smaller than in $L$. cyanellus, the supplemental maxillary larger; maxillary $2 \frac{2}{3}$ in head. Gill-rakers long and slender.

Color in spirits very dark. Soft dorsal mottled with darker, and in 3 specimens provided with a black ocellus; fins all dusky. Small speci- 
Vol. VII, No. 21. Washington, T. C. Sept.1, 1884.

mens show faint blue spots on sides of head, and there are traces of about ten irregular dusky cross-bands. Opercular spot large, confined to the bone.

Body formed much as in L. humilis.

21. Lepomis miniatus, Jordan. 35214, (2).

This species much resembles the preceding, in spirits, but reaches a larger size. It has much shorter gill-rakers, smaller scales, a different structure of the maxillary, \&c.

Scales, 5-40-12.

22. Lepomis pallidus, (Mitchill.) 35212.

23. Chænobryttus gulosus, (Cuv. \& Val.). $35203 ; 35206 ; 32411 ; 35231$.

Many specimens.

24. Pomoxys sparoides, Lac. 35228.

D. VII, 13. Depth $2 \frac{1}{5}$ in length, being, like most specimens from the Gulf States, more elongate than is usually the case with Northern examples of the same species.

25. Haploidomotus grunniens, (Raf.). $35240 ; 35242$.

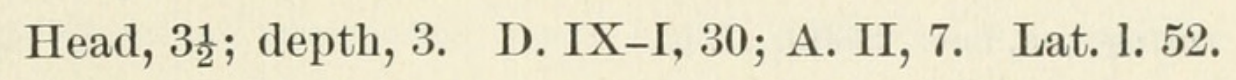

26. Gobius würdemanni, Girard. 35202 (23 specimens).

Closely allied to G. stigmaturus, G. boleosoma, and G. enccomus.

Head, $3 \frac{2}{5}$ to $3 \frac{2}{3}$; depth, $5 \frac{1}{3}$. D. VI-12; A.13. Scales, 32 to 35 . Length, of largest specimens about $3 \frac{1}{2}$ inches.

Body moderately elongate, subfusiform. Head large, not very blunt; anterior profile gently decurved; snout $3 \frac{1}{3}$ to $3 \frac{1}{2}$ in head; eye 4 ; mouth large, slightly oblique, the maxillary reaching anterior border of pupil $2 \frac{1}{3}$ in head; teeth small, in moderate bands, slender and curved, the outer above little enlarged, not canine-like; lower jaw slightly included.

Scales moderate, ctenoid rather loosely attached; those on anterior part of body much reduced in size. Head, breast, and a narrow strip before dorsal naked.

Dorsal spines slender, none of them filamentous, the longest nearly $\frac{2}{3}$ head. Soft dorsal and anal low. Caudal pointed, about as long as head. Pectoral, $1 \frac{2}{3}$ in head; ventral, $1 \frac{1}{5}$.

Color, in spirits, light olive, irregularly shaded with darker and with gray; the pale markings much less conspicuous than in G. stigmaturus. About five rounded dark blotches along median line of sides, the number irregular, the posterior one most distinct, forming a spot at base of caudal. A dusky blotch on opercle; two dark streaks below eye; some dusky cross-streaks on top of head. No dark blotch on sides of nape.

Proc. Nat. Mus. $84-21$ 
Both dorsals and caudal with dark cross streaks. Pectoral faintly crossbarred; two or three small dusky spots on its base.

This species is probably the one named by Girard, Gobius wiirdemanni. Girard's description is, however, so short and so carelessly written as to be of little value for purposes of identification. This description however applies to this species better than to any of its relatives found on the Gulf coast. I have therefore preferred to regard this as the true wïrdemanni, rather than to apply to it a new name.

Smithisonian Institution, August 1, 1884.

LIST OF FISHES COLLECTED IN LAKE JESSUP, AND INDIAN RIVER, FLORIDA, BY MR. R. E. EARLL, WITH DESCRIPTIONS OF TWO NEW SPECIES.

\section{BY DA VID S. JOIRAN.}

In the year 1880 a collection of small fishes was made in Lake Jessup, Florida, a tributary of Saint John's River, and in the Indian River, near Titusville, Fla. Several interesting forms were obtained, among them two which appear to be new to science. The following is a list of the species. L. J. indicates Lake Jessup ; I. R., Indian River :

1. Jordanella floridæ, Goode \& Bean. 25345. I. R.

2. Cyprinodon variegatus, Lac. 25313. I. R.

3. Fundulus similis, Baird \& Girard. 25317. I. R.

4. Fundulus seminolis, Girard. 25323. L. J.

D. 17. A. 14. Scales, 54-18.

Coloration rather pale; each scale with a small darker spot, these forming longitudinal stripes, the spots not coalescent. Dorsal with whitish and dusky spots arranged in cross series; caudal with cross series of dark spots. Lower fins plain. A small dusky spot above base of pectoral. Head rather long, narrow, and pointed. Interorbital width equal to length of snout, $2 \frac{3}{4}$ in head. Eye, 4 in head. Teeth in a broad band, the outer little enlarged.

This is a large, sleek-looking species, very distinct from all the others in the genus.

5. Fundulus heteroclitus, (L.). 25310. I. R.

6. Zygonectes henshalli, Jordan. 25330. I. R.

7. Zygonectes chrysotus, Günther. 35299. I. R.

8. Gambusia patruelis, (B. \& G.). 25327; 25333; 25344. I. R.

A multitude of specimens of various sizes. Some have the black blotch below the eye very distinct; in others it is obscure, or altogether obsolete. Some of the largest and deepest colored females correspond exactly to the type of Zygonectes inurus. Others match almost perfectly 


\section{$2 \mathrm{BHL}$ Biodiversity Heritage Library}

Jordan, David Starr. 1884. "List of fishes collected in the vicinity of New Orleans by Dr. R. W. Shufeldt, U.S.A." Proceedings of the United States National Museum 7(437), 318-322. https://doi.org/10.5479/si.00963801.7-437.318.

View This Item Online: https://www.biodiversitylibrary.org/item/31798

DOI: https://doi.org/10.5479/si.00963801.7-437.318

Permalink: https://www.biodiversitylibrary.org/partpdf/11569

\section{Holding Institution}

Smithsonian Libraries

\section{Sponsored by}

Smithsonian

\section{Copyright \& Reuse}

Copyright Status: NOT_IN_COPYRIGHT

This document was created from content at the Biodiversity Heritage Library, the world's largest open access digital library for biodiversity literature and archives. Visit BHL at https://www.biodiversitylibrary.org. 